\title{
ECONOMIC AND SOCIAL SECURITY IN EU: REFORMING SLOVENIAN LAW ON SOCIAL ENTERPRENEURSHIP
}

\author{
Petra Kleindienst \\ School of Advanced Social Studies, Slovenia \\ E-mail: petra.kleindienst@fuds.si
}

\begin{abstract}
Europe 2020 strategy of smart, sustainable and inclusive growth also implies policies for boosting social innovations. In this context, it is relevant to encourage solutions such as social entrepreneurship as it is addressing social and environmental issues while employing entrepreneurship. Social entrepreneurship depends on the context of its emergence and implementation. In this regard, the context-specific factors play an important role. Following the Cultural Political Economy approach, the article examines on different factors that have influenced on the adoption of amendments of the Slovenian Social Entrepreneurship Act in 2018. Selection of the case study of Slovenia bases on the findings implying that Slovenia has still not overcome the initial phase of the development of the social entrepreneurship. The article reveals that there are still issues relevant for running social enterprises that are not sufficiently regulated by the law. One of them is a training of the vulnerable groups in terms of their technological skills in order to ensure their efficiency and productiveness in Work Integration Social Enterprises.
\end{abstract}

Key-words: social entrepreneurship, social innovations, technology, legislation, Europe 2020

\section{Introduction}

Social entrepreneurship is following social mission that focuses on creating systemic and sustainable change while addressing the needs of others (Beugré 2017); it applies the needs of the principles of social responsibility. It is a key element of the European social model and is closely linked to the Europe 2020 strategy (Tomaževič and Cantele 2019). As such, social entrepreneurship contributes to the smart, sustainable and inclusive growth. Development of social entrepreneurship is very context specific, shaped by wider social, economic, cultural, historical, institutional and other development patterns (OECD/European Commission 2013). As social enterprises depend on the contexts in which they operate, the barriers that they face are specific to those contexts (Bradač Hojnik 2017). These contexts 
can be complex, employing a variety of dimensions (see Adam et al. 2005). The development of appropriate legal, regulatory and fiscal frameworks of social entrepreneurship must therefore emerge from the environments in which social enterprises operate. At the same time, such frameworks must be adapted to the proper organisational form that social enterprises may take (OECD/European Commission 2013). Due to the heterogeneity of social entrepreneurship, the causes and consequences of social entrepreneurship are often multi-factorial. This can result in policies that do not translate into impact (Phan 2014). The article discusses the policies and legal landscape of social entrepreneurship in Slovenia. Establishing proper policies is relevant as policy makers can help social enterprises overcome self-restraining behaviours and select the most suitable strategies (OECD/European Commission 2013). Thus, it is important to explore factors, circumstances and also specific mechanisms that have led to the new policies and reforms on the law of social entrepreneurship. This is highly important since societal steering requires not only politically accepted grand strategies, but also ex-ante theoretical, conceptual and analytical considerations (Rončević and Makarovič 2010, Rončević and Makarovič 2011, Rončević 2008; Rončević et al. 2010).

The purpose of the article is to provide the general overview of the Slovenian legal framework on social entrepreneurship as well as recognize political, social, economic and other conditions that have led to the reform of Slovenian legislation on social entrepreneurship in 2018. In order to achieve the main puporse of the article, the second chapter of the article tackles the main factors that have fostered the development of social entrepreneurship across Europe, with a special focus on Slovenia. In the third chapter, the main problems regarding the growth of social entrepreneurship in Slovenia, in relation to Slovenian legislative barriers on social entrepreneurship are represented. On the base of that, the main reasons and factors for adoption of amendments of the Slovenian Social Entrepreneurship Act in 2018 are represented.

Following from all that, the article goes in line with principles of cultural political economy (CPE) as an emerging post-disciplinary approach that highlights the contribution of the cultural turn (a concern with semiosis or meaning-making) to the analysis of the articulation between the economic and the political and their embedding in broader sets of social relations (Jessop 2010). CPE explores three generic evolutionary mechanisms: variation, selection, and retention (Campbell 1969; Jessop 2004; Jessop 2010): 
1) Variation in discourses and practices, due to their incomplete mastery, their skilful adaptation in specific circumstances, new challenges or crises, or other semiotic or material causes (Jessop 2010). In our case study, a variation could be seen in the public discourses about the current needs of social enterpreneurship as well as its possible adapations considering the new circumstanes and challenges of social enterpreneurship in Slovenia. In our case study, public discourse involved the actors such as scientific and professional institutions, NGOs, individual experts, civil society etc.

2) Selection of particular discourses (the privileging of just some available, including emergent, discourses) for interpreting events, legitimizing actions, and (perhaps self-reflexively) representing social phenomena (Jessop 2010). In terms of our case study, the mechanism of selection was employed when facing a shift of political discourses about social enterpreneurship as some political discourses prevailed in 2018. Semiotic factors acted here by influencing the resonance of discourses in personal, organizational and institutional, and broader meta-narrative terms and by limiting possible combinations of semiosis and semiotic practices in a given semiotic order (Jessop 2010).

3) In our case study, the retention of some resonant discourses could be seen in integration of the solutions (as a result of prevailing discourses about social enterpreneurship) into institutional rules, i.e. Slovenian Social Enterpreneurship Act (2018), national strategies etc.

However, the article reveals that there exist noticeable challenges in the field of Slovenian social entrepreneurship that are still not sufficiently addressed by the legislation, for example, the issue of labour force' skills in WISEs (Work Integration Social Enterprises), mainly in relation to the requirements posed by technological progress and economic innovation. According to European Commission (2015), WISEs are a special type of social enterprise that display the following minimum characteristics: a) private and autonomous enterprises operating on the market; b) disadvantaged workers have employee rights under national labour law; c) core mission is the integration through work of disadvantaged people; d) compliance with a minimum threshold of disadvantaged workers over total workforce. In general, European country reports on social entrepreneurship typically emphasize the relevance of business, management and marketing skills of social entrepreneurs for the successful emergence and running of their enterprises. However, those reports often do not raise the importance of technologically skilled labour force in order to ensure the efficiency and productiveness of social enterprises. This is particularly true for WISEs that are working for the integration of vulnerable groups and often suffer from 
technological gaps. Thereby, the last chapter of the article offers the analysis of Slovenian legal documents in order to recognize shortages within legal framework and thereby detect potential encouragements of labour force's technological skills in WISEs.

\section{The Revival of the Social Enterprise Sector}

Generally speaking, the negative effects of neoliberal policies have since long contributed the focus on social quality aspects of development (Fairweather et al. 2001) and related approaches, including social entrepreneurship, which is spreading at a rapid pace in the entire Europe. Taking mediocre implementation record of the EU grand strategies into account (Makarovič et al. 2014), it can play important role in implementation of the recent Europe 2020. The social economy offers new possibilities for the innovative employment of vulnerable target groups aiming to enable companies of this kind to independently generate revenue and survive (Trampuš, Cankar and Setnikar Cankar 2013). EU documents refer to social entrepreneurship when striving for the growth of social economy and social innovations, creating a favourable climate for social enterprises; for example: European Platform against Poverty and Social Exclusion, The Innovation Union, Europe 2020 Strategy, Single Market Act - Twelve levers to boost growth and strengthen confidence. EU Operational Definition of Social Enterprise implies three dimensions of social enterprises (European Commission 2015):

1. Entrepreneurial dimension - social enterprises show the typical characteristics that are shared by all enterprises;

2. Social dimension - social enterprises pursue an explicit social aim; primacy of social aim over commercial objectives;

3. Governance dimension - social enterprises have specific governance structures to safeguard their social missions.

However, EU legislation does not include a uniform definition of social enterprise. Thus, the definition of the latter in EU member states varies according to different factors and circumstances of particular country.

EU has funded several research projects on the social entrepreneurship (see European Commission 2015), for example: Social Enterprise as a Force for more Inclusive and Innovative Societies (SEFORÏS); Enabling the Flourishing and Evolution of Social Entrepreneurship for Innovative and Inclusive Societies (EFESEIIS); Social Entrepreneurs as Lead Users for Social Innovation (SELUSI); The Theoretical, Empirical and Policy Foundations for Social Innovation in Europe (TEPSIE). Those projects are mainly focussed on understanding of social enterprises in Europe; fostering social 
entrepreneurship and social innovation; identifying the features of an enabling eco-system for social entrepreneurship; identifying constraints as well as contribution of social entrepreneurs to social innovation.

The revival of the social enterprise sector in recent few years can be explained by the impact of the economic crisis leading to rising interest in alternative economic development models (European Commission 2014). Therefore, there exist a big potential for further development of social entrepreneurship in Slovenia, which could help to diminish a problem of structural unemployment (Adam et al. 2015). A new type of social economy in Slovenia is evolving after the dissolution of the socio-economic selfgovernance system and the associated labour law of the former federal country Yugoslavia, of which Slovenia was one of the federal republics. Before 1990, Slovene citizens experienced both high levels of employment and social welfare services under self-managed socialistic communities and societies (Doherty at al. 2009). After the change of the economic system in Slovenia in the late 80ies and the loss of Yugoslav markets, unemployment in Slovenia increased substantially (Institute for Economic Research, Slovenia 2010). Hence, Slovenian citizens are still quite confused about the term social economy and social entrepreneurship. This is partly also due to the fact that entrepreneurship during the transition became associated with entrepreneurs who had no social conscience (Doherty et al. 2009). However, Slovenia is facing poor knowledge and lack of understanding of the concept of social entrepreneurship, its principles, goals and benefits; the concept of social economy is not widely known and accepted in Slovenian public (Macura and Konda 2016). Despite adoption of legal framework for establishment of social enterprises which is in accordance with EU regulation, Slovenia has not yet overcome the initial phase of the development of the social entrepreneurship, which lags Slovenia behind other EU members. This fact was confirmed, for example, by OECD project (Spear et al. 2010) and CIRIEC (2012).

For successful running of the social enterprises, a proper entrepreneurial knowledge is needed. Unfortunately, social entrepreneurship sector is facing the lack of business knowledge, management and marketing skills as well as experience of social entrepreneurs. Therefore, there is a need to build supportive environment for social entrepreneurship. Podmenik, Adam and Milosevic (2017) have identified three key levels of supportive environment for social entrepreneurship in Slovenia:

- national level (effective implementation of legislation; systemic regulation and integration of social entrepreneurship in all key documents; interdepartmental coordination in the planning and implementation of 
policies and relevant operational program measures in different incentives for social entrepreneurship; guaranteeing proper fiscal incentives and tax exemptions; enhanced cooperation of state institutions with social enterprises and other organizations in the planning and implementation of measures to support the development of social entrepreneurship; raising awareness and knowledge on social entrepreneurship);

- municipal level (integration of projects related to the social entrepreneurship into local development programs and establishing concrete incentives and resources for support of social entrepreneurship; ensuring the functioning of regional networks to support social entrepreneurship; activation of untapped local resources (land, buildings, equipment) held by the local community to support the social entrepreneurship; financial support to employment programs of social enterprises.

- organisational level (mostly NGO sector) which responds to the local needs.

\section{Factor Influencing the Adoption of Amendments of Slovenian Law on Social Entrepreurship}

In Slovenia, the concept of social entrepreneurship is relatively new. It was hardly used until 2009 when an EU-funded pilot programme to support the development of social enterprise was launched (European Commission 2014). Legal basis for social entrepreneurship was established in 2011 when Social Entrepreneurship Act (2011) ${ }^{1}$ was adopted. Social Entrepreneurship Act was followed by the Rules on Monitoring Operations of Social Enterprises (2013)2 . The Strategy for Social Entrepreneurship for the period 2013-2016 and related Programme of Measures 2014-2015 for conducting the Strategy for Social Entrepreneurship were lately adopted (2013). For the purpose of accountancy in the field of social entrepreneurship, Slovenian Accounting standards (2016) encompass "Accounting solutions in social enterprises". Several studies in the field of social entrepreneurship were conducted in Slovenia and their number especially increased from the adoption of Social Entrepreneurship Act on. Lužar Šajt et al. (2005), for example, offers an

\footnotetext{
1 This act includes content on general provisions, definition of social enterprise, operating conditions of social enterprises, an environment conducive to social entrepreneurship development, special incentives to social entrepreneurship, register of social enterprises, supervision, penal provisions, transitional and final provisions.

2 This act determines the means of monitoring the activities of social enterprises and defines the bodies that are authorized for monitoring.
} 
overview of existing conditions, activities and potential opportunities in relation to the development of social entrepreneurship. Spaer et al. (2010), European Commission (2014) and Adam et al. (2015) imply main challenges and problems in the development of social entrepreneurship as well. Further, Hrast et al. (2014) indicates the social impact of social enterprises in Slovenia. In February 2018, an applicative analysis of the situation in the field of social economy in Slovenia was prepared. It contains the guidelines for the preparation of the long-term strategy for the development of the social economy in Slovenia 2019-2029 and the program of short-term measures with the action plan 2019-2020 (Ministry of Economic Development and Technology, N.d.). However, Slovenia amended the Social Entrepreneurship Act in 2018.

European Commission (2014) reported that the register of social enterprises in Slovenia had not covered the entire spectrum of social enterprises in Slovenia. This was partly due to the strict criteria to maintain the status of social enterprises and no public financial advantage offered apart from existing Ministry of Labour, Family, Social Affairs and Equal Opportunities measures. ${ }^{3}$ The study estimated there were around 900 organisations which have potentially felt within EU operational definition at that time (ibid.). Social entrepreneurs have shared the opinion that legal framework in Slovenia offers demanding and strict conditions for operating the social enterprises, intertwined with insufficient flexibility of measures of active employment policy. Hence, Slovenian legal framework was perceived as a rigid one; the one that does not foster the growth of social entrepreneurship. Podmenik, Adam and Milosevic (2017) have identified different types of organisations in Slovenia that can be generally classified as social enterprises despite the fact that they are belonging to different socioeconomic sectors: social enterprises registered under Social Entrepreneurship Act (associations, private institutes, cooperatives, and private organizations with limited liability); disability companies and employment centres; cooperatives; non-governmental organizations; companies with positive social externalities or social responsible enterprises.

Currently, there exist a few supporting services in Slovenia (e.g. SPIRIT, CNVOS, Social Incubator, Successful Entrepreneur Institute, Fund 05 Foundation for Social and Impact Investment etc.) which can equip social entrepreneurs with a proper business knowledge; help social entrepreneurs

\footnotetext{
${ }^{3}$ From January 1, 2015, the Ministry of Economic Development and Technology is responsible for the field of social entrepreneurship.
} 
to develop business idea and design business plan; and consult them about other relevant issues regarding running a social enterprise. Having a need for business consultations, the social enterprises come across the financial issue, namely limited budget of social entrepreneurs and the lack of (private and governmental) investments in social entrepreneurship, which is one of the biggest problems of social entrepreneurship sector in Slovenia. In fact, the social enterprises have been more likely to survive if there is the funding at the national or EU level available. ${ }^{4}$ In this regard, social entrepreneurs have largely relied on subsidies for employment of vulnerable groups. In 2014, European Commission reported that measures and funding for fostering social entrepreneurship in Slovenia had been primarily focused to the social enterprises of type B. ${ }^{5}$ According to Macura and Konda (2016), Slovenia lacks mechanisms for financial investments in social enterprises. Social enterprises face difficulties to access to financial resources, which includes more favourable loans for employment, as well as providing guarantees and subsidies from the budget.

In Slovenia, there is certainly a problem from a systemic perspective as well. In 2011, the Council for Social Entrepreneurship has been established. In 2018, it was renamed to the Council for Social Economy. Its main role is designing the social entrepreneurship policy, in cooperation with ministries, governmental organizations, municipalities, social partners and organizations of civil society. However, the cooperation between the institutions responsible for the development of social entrepreneurship is still insufficient (Macura and Konda 2016), which makes social entrepreneurship difficult to grow at national as well as local level. Furthermore, there is no proper statistical monitoring of the social entrepreneurship sector as a separate entity, therefore the size and structure of the social entrepreneurship sector can be given only on qualitative assessment (Podmenik, Adam and Milosevic 2017). There are also only a very limited numbers of public measures implemented in Slovenia which are specifically designed for social enterprises (European Commission 2014). Additionally, Slovenia consists of a large number of diverse organizations, fragmented across different sectors and lacks visibility as a homogeneous group (Podmenik, Adam and Milosevic 2017).

\footnotetext{
4 An overview of national vs. EU funds as planned by Slovenian Programme of Measures for the period $2014-2015$, for example, indicates $44 \%$ of the total funding covered by national funds and $56 \%$ by the EU (European Commission 2014).

5 For the explanation of the social entreprises of the type $B$, see the next chapter.
} 
To summarize, the scope of previous legislation of the Republic of Slovenia on social entrepreneurship, which was generally in line with the EU legislation, was very narrow and rigid. Social Entrepreneurship Act and other relevant legal documents, referred to a large range of administrative barriers which made social enterprises difficult to develop and grow. There was (and is still) present a big concern in terms of insufficient understanding of social entrepreneurship among the general public as well as financial issue and search for building supportive environment for development of social enterprises. Thus, the Social Entrepreneurship Act was amended in 2018.

According to the Government of the Republic of Slovenia (2018), the key objectives of adopting the Social Entrepreneurship Act amendments were:

- strengthening the functioning of social enterprises on the principle of market orientation,

- increasing the number of registered social enterprises,

- increasing the number of jobs provided by social enterprises,

- increasing the positive social effects social enterprises provide through the implementation of their business activities,

- increasing the GDP generated by social enterprises,

- removing administrative barriers to social enterprise registration procedures,

- enabling the status of social enterprise for disability companies and employment centre.

\section{Current Slovenian Legislation on Social Entrepreneurship}

According to the Slovenian Social Entrepreneurship Act (2018, Article 3), social entrepreneurship shall represent the permanent performance of entrepreneurial activities in the manufacture and sales of products or the provision of services on the market, for which the generation of profit is not a main objective; rather, the main goal is to achieve social impacts. Slovenian legislation determines the main objectives of the social entrepreneurship: strengthening social solidarity and cohesion; promoting the participation of people; improving society's capacity for innovation in addressing social, economic, environmental and other issues; stimulates social innovations; ensuring the additional supply of products and services in the public interest; developing new employment possibilities; providing additional jobs and enabling social integration and vocational (re)integration of the disadvantaged groups in the labour market (ibid., Article 3). Additionally, the Social Entrepreneurship Act (2018) redefines the term of the most vulnerable groups in the labour market: these include disadvantaged workers, seriously 
disadvantaged workers and disabled people. By (re)definitions in Social Entrepreneurship Act (2018; Article 2), additional vulnerable target groups in the labour market are encompassed by the Social Entrepreneurship Act (2018), for example, young people who want to enter the labour market, or people being retrained.

The last amendments of the Slovenian Social Entrepreneurship Act (2018) imply the significance of social innovations as one of the main contributions or goals of social entrepreneurship. From 2018 on, Social Entrepreneurship Act also provides a definition of social innovation: a social innovation is a solution to social needs and problems for which the market and the public sector have no proper responses (ibid., Article 2). According to the Social Entrepreneurship Act (2018), the main aim of a social innovation is to achieve social impact. A trend of noticeable emphasizing social innovations and social impacts of social enterprises can be perceived in Slovenian legislation. This can be interpreted as a positive step since some case studies (for example, Tomaževič and Aristovnik 2018) encourages policy makers and the businessmen to start raising awareness about business structures with a corporate aim of having a positive social impact and addressing social objectives rather than only maximising profit.

The social enterprise is supposed to pursue the following principles, which indicate its nature of social contribution (Social Entrepreneurship Act, Article 3):

- it is established by the voluntary decision of its founders (autonomous initiative);

- its purpose is not solely to generate profit, assets and surplus revenue over expenditure are used for the activities of social enterprise, surplus revenue over expenditure distribution is not allowed (non-profitability);

- it is established with the main purpose of continuously engaging activities with a view to employing the most disadvantaged groups in the labour market, which is also a public interest (performance of activities in the public interest);

- its members work voluntarily (voluntariness);

- it is managed independently (independence);

- the manufacture and sale of its products or the provision of its services in the market are organised according to market principles (market orientation);

- it can involve voluntary work (voluntary work participation);

- individual founders or owners do not exercise dominant influence over decision-making; decisions are adopted by all members according to the 
principle one member-one vote, and irrespective of their equity share (equality of members);

- the stakeholders are involved in decision making (stakeholder participation in management);

- it provides for the transparency of its financial operation and for internal control over its inventory management and financial operations (operations transparency);

- it permanently performs its activities for the benefit of its members, users and the wider community (operating for the social benefit).

There is a trend of broadening a scope of activities of social enterprises, covered by the Slovenian Social Entrepreneurship Act. From 2018 on, the areas in which social entrepreneurship activities can be conducted are no longer defined by law. Thereby, the activities of social entrepreneurship can be implementes in all economic and non-economic areas (Social Entrepreneurship Act, Article 5).

Social Entrepreneurship Act (2011, Article 8) indicated a clear distinction between two types of social enterprises: more business oriented social enterprises (Type A) and social enterprises established with a view to employing people from vulnerable groups (Type B; Work-integration social enterprises - WISEs). ${ }^{6}$ The legal basis for the establishment of a mixed type (A-B) of social enterprises was not provided by the law. The Social Entrepreneurship Act (2018) does no longer differentiate between Type A and Type B. Thereby, all social enterprises are expected to implement economic activity in order to ensure permanent business that follows market orientation principles.

Under previous legislation, the disability companies and employment centres could not be registered as a social enterprise (European Commission 2014). According to MLFSA, the reason for not allowing double registration was to prevent double funding as there was public funding for disability companies and employment centres available, provided by the Vocational Rehabilitation and Employment of Disabled Persons Act (2004; European Commission 2014). However, the amendments of Social Entrepreneurship

\footnotetext{
${ }^{6}$ According to the Social Entrepreneurship Act (2011), there were conditions for both types of social enterprises: social enterprises of a type A were supposed to perform social entrepreneurship activities specified by the law and employ at least one worker in the first year of its operation and at least two workers in subsequent years. Social enterprises of a type B were supposed to establish with a view to employing people from vulnerable groups and being engaged in a particular activity by permanently employing at least one third of these workers out of the total staff.
} 
Act (2018) have eliminated restrictions for registration of disability companies and employment centres as social enterprises, aiming to achieve a larger proportion of existing social entrepreneurs to register their social enterprises.

\section{Shortages of Current Slovenian Legislation on Social Enterpreurship}

There are still numerous concerns regarding the functioning of social enterprises that are not tackled in the current legislation. One of them is definitely training of people from vulnerable groups in terms of their technological skills in order to ensure their efficiency and productiveness in WISEs. It is interesting that countries' reports on social entrepreneurship usually largely emphasize the relevance of business, management and marketing skills of social entrepreneurs, meanwhile those reports do not expose the meaning of the skilled labour force in social enterprises. In this regard, SMEs in Central Europe, particularly WISEs, currently face shortages, mainly in relation to the requirements posed by technological progress and economic innovation. This is particularly true for WISEs which are working for the integration of vulnerable groups. They do often suffer from technological gaps due to the low investment levels and lack of necessary skills.

ICT is becoming increasingly important for establishment and effectiveness of social entrepreneurship. It is important to understand that ICT represents an added value for building and sustaining of social enterprise's competitiveness as well as an important tool for business strategy (Torres Coronas and Vidal Blasco 2013). Freeman and Freeman (2013) stress that with the evolution of ICT and the recognition of the humanity of individuals with disabilities, we are coming to a time of inclusion of all within our society. Through the utilization of ICT the individuals with disabilities gain a sense of self-worth and self-determination; and society gains through a more satisfied population and a more diverse and inclusive business sector (ibid.). Therefore, there is a need to research the ICT skills that are needed to develop in order to ensure engagement of the disabled into social enterprises and raise their productivity and effectiveness. This requires additional trainings of the disabled and their capacity buildings activities. According to Freeman and Freeman (ibid.), the need for technological training of ICT skills of the disabled people is clear, but only little research explores how this can be done in practical setting. This chapter offers an analysis of 
Slovenian legislation in order to indicates insufficient legal conditions for training of the ICT skills of disabled for conducting their work in WISEs.

There are some measures/incentives in place to support employment of the disabled and other vulnerable groups in Slovenia (European Commission 2014). But for successful running of social enterprises, there are financial resources and subsidies needed for social enterprises that train people from vulnerable groups and enhancing their knowledge and skills. In Slovenia, encouragement of employment of the disabled in social enterprises was one of the strategic goals (Strategic Goal No. 3) in accordance with Strategy of Social entrepreneurship for the period 2013-2016 and Program of Measures 2014-2015. For this purpose, some of the foreseen measures included training and workshops for social enterprises of type B. 7 More specifically, the activities encompassed development of the model of workshops as well as the implementation of created model in the social enterprises. The purpose of these activities was to train unemployed disabled persons through workshops in order to improve their employment opportunities; increasing their competitiveness in the labour market; gaining and strengthening their skills. Workshops have been carried out in social enterprises of type B and non-profit legal organizations which operated as social enterprises of type B. The workshops have been addressed to vulnerable groups (target groups) that do not have employment opportunities due to their insufficient skills and work experience (see Program of Measures 2014-2015).

In order to develop the model of workshops, analysis of employment of vulnerable groups was conducted by Šent (2014), on the behalf of Ministry of Labour, Family, Social Affairs and Equal Opportunities of the Republic Slovenia. The research identified the digital literacy and computer knowledge as relatively important competences for carrying out the work in social enterprises, disability companies and employment centres. This research implies that ICT skills of disabled are not sufficiently developed and trained. Similar results were brought up by the study in 2013 (Šent 2013), financed by European Regional Development Fund, focused on a supportive environment for the development of social entrepreneurship in Slovenia.

National guidelines to improve built environment, information and communications accessibility for people with disabilities (2005) aim to integrate the disabled to employment environment as well as society. Furthermore, Guidelines for the Implementation of Active Employment Policy Measures for the Period 2016-2020 (2015) encourage the training and

7 The Social Entrepreneurship Act (2018) does no longer differentiate between Type A and Type B. 
education of vulnerable groups but this document does not explicitly mention the disabled (but only unemployed people, young people and elderly). In accordance with the Vocational Rehabilitation and Employment of Persons with Disabilities Act (2007), a disabled person has the right to vocational rehabilitation. The latter include services that aim to qualify a disabled person for suitable work, to help to disabled to retain employment and to progress in terms of his/her professional career (Article 4). Finally, Resolution on the Master Plan for Adult Education in the Republic of Slovenia for 2013-2020 (2013) specifies the disabled as a target group and aims to raise the digital literacy of the disabled and their integration in information society.

The range of Slovenian legal documents on the discussed topic is extensive. This article mentions only those documents that are the most relevant to achieve the purpose of the article. All the legal documents mentioned above primarily strive to increase employability of the disabled, prevent the discrimination of the disabled at labour market and integrate the disabled into employment environment. For this purpose, some of the legal documents provide the rights of the disabled to their vocational rehabilitation, training and education. However, competences and skills that should be provided to the disabled during their trainings, are not specified. Hence, the only relevant research in this regard is Šent (2014) which exposes the list of the relevant competences and skills that should be fostered in WISEs. Moreover, there are no legal documents as well as research in Slovenia that focus specifically on building ICT skills of the disabled person in the field of social entrepreneurship. In this perspective, the contribution of project INNOWISEs covered by the Interreg Central Europe Programme (N.d.) which was launched in 2017 might be relevant to the further development of social entrepreneurship. The aim of the project is to create a knowledge management framework, a flexible digital communication platform and training programmes. By connecting actors from work integration social enterprises, research, technological experts and relevant public authorities, the project strives to change the entrepreneurial mind-set, skills and attitude of the sector thus building and promoting a stronger culture of entrepreneurship and greater social cohesion.

\section{Conclusion}

If the legislation provides more incentives for developing technological skills of labour force in WISEs, it could accelerate the business development of social enterprises, and in particular contribute to effective solutions to social issues and thus provide greater social impact. For this purpose, clear legal 
definitions of the social enterprises are needed. Additionally, the amendments to the Slovenian Social Entrepreneurship Act meant a step forward as removing bureaucratic barriers that have discouraged entrepreneurs from registration of a social enterprise. Disability companies or employment centres are now allowed to obtain a status of social enterprise. According to the amendments of the Slovenian legal framework of social entrepreneurship, we can recognize a trend of broadening a scope of activities of social enterprises. From 2018 on, the areas in which social entrepreneurship activities can be conducted are no longer defined by law. Thereby, now the activities of social entrepreneurship can be implemented in all economic and non-economic areas.

Following the Europe 2020 strategy, it is important to invest in science and research and ensure the transfer of the research findings into economy and social issues. In line with that, there is a constant need to adapt policies and legal framework of social entrepreneurship to the prevailing needs of the society. There are still many possibilities for progress in this regard. This article showed an example of possible adaptations, i.e. the establishment and implementation of policies bringing incentives for encouraging ICT skills of the vulnerable groups in WISEs.

However, the success of national, regional and international policies of social entrepreneurship largely depend on the value-context as well. We consider values as part of social order. Values are perceived as social constructs that are constituted when most members of a particular community recognize them as a common ground of the community. Values can be defined as principles that people are supposed to follow through the course of their lives and actions. We can say that values indicate standards of social behaviours that guide interactions between people and human behaviour. They provide social stability and represent goals or motives on the basis of which an individual act in a particular situation. According to Conger (2012), personal values affect social entrepreneurs to create non-economic value. Additionally, social entrepreneur must account for the value priorities of other stakeholders associated with their venture. Social entrepreneurship is often based on ethical motives and moral responsibility and altruism; however, the motives for social entrepreneurship can also include less altruistic reasons such as personal fulfilment (Meir and Marti Lanuza 2006). A value-context of social enterpreneurship is still relatively under-examined and offers many opportunities for future research. 


\section{References}

Adam, Frane (ed.). 2015. $O$ stanju in perspektivah socialnega podjetništva $v$ Sloveniji in Hrvaški. Ljubljana: Inštitut za razvojne in strateške analize.

Adam, Frane, Matej Makarovič, Borut Rončević and Matevž Tomšič. 2005. The Challenges of Sustained Development: The Role of Socio-cultural Factors in East-Central Europe. Budapest and New York: Central European University Press.

Beugré, Constant. 2017. Social Entrepreneurship: Managing the Creation of Social Value. New York and London: Routledge.

Bradač Hojnik, Barbara. 2017. "Approach to Social Entrepreneurship in Slovenia." International Conference on Innovations in Science and Education. Prague. Doi: 10.12955/cbup.v5.903.

Campbell, Donald T. 1969. "Variation and selective retention in socio-cultural evolution." General Systems 14: 69-86.

CIRIEC (International Centre of Research and Information on the Public, Social and Cooperative Economy). 2012. The Social Economy in the European Union. Report drawn up for the European Economic and Social Committee. http://www.eesc.europa.eu/resources/docs/qe-30-12-790-en-c.pdf. Accessed July 3, 2018.

Conger, Michael. 2012. "The role of personal values in social entrepreneurship." In Patterns in Social Entrepreneurship Research, edited by Jill Kickul and Sophie Bacq. Cheltenham, UK / Northampton, MA, USA: Edward Elgar.

Doherty, Bob, George Foster, Chris Mason, John Meehan, Karon Meehan, Neil Rotheroe and Maureen Royce. 2009. Management for Social Enterprise. Sage Publications.

European Commission. 2014. A map of social enterprises and their eco-systems in Europe. Country Report: Slovenia.

http://ec.europa.eu/social/keyDocuments.jsp?advSearchKey=socentcntryre pts\&mode=advancedSubmit\&langI\&langId=en. Accessed July 3, 2018. 
European Commission. 2015. A map of social enterprises and their eco-systems in Europe Synthesis Report.

www.ec.europa.eu/social/BlobServlet?docId=12987\&langId=en.

Accessed July 3, 2018.

Fairweather, Anne, Borut Rončević, Maj Rydbjerg, Marie Valentova and Mojca Zajc. 2001. "Reconceptualisation od Social Quality." European Journal of Social Quality 3 (1-2): 118-143.

Freeman, Ina and Aiofe Freeman. 2013. "Capacity Building for Different Abilities Using ICT". In Social E-Enterprise: Value Creation through ICT: Value Creation through ICT. Hershey/PA: IGI Global.

Government of the Republic of Slovenia. 2018. Law Amending the Law on Social Entrepreneurship.

https://skupnostobcin.si/wp-

content/uploads/2018/01/49b91ba52c814d04ae01.pdf.

Accessed May 1, 2019.

Guidelines for the Implementation of Active Employment Policy Measures for the Period 2016-2020 (2015). Ministry of Labour, Family, Social Affairs and Equal Opportunities of the Republic Slovenia.

http://www.mddsz.gov.si/fileadmin/mddsz.gov.si/pageuploads/dokumenti _pdf/zaposlovanje/Smernice_APZ_2016_2020_final.pdf. Accessed July 3, 2018.

Hrast, Anita, Sabina Kojc and Matjaž Mulej. 2014. Študija in model merjenja družbenih učinkov socialnih podjetij v Sloveniji. Inštitut IRDO.

Institute for Economic Research, Slovenia. 2010. Social Enterprise Sector in Slovenia. Report prepared for ISEDE-NET project. Draft. www.southeasteurope.net/document.cmt?id=196

Interreg Central Europe Programme. N.d. INNO-WISEs. https://www.interreg-central.eu/Content.Node/INNO-WISEs.html. Accessed April 3, 2019.

Jessop, Bob. 2004. "Critical semiotic analysis and cultural political economy." Critical Discourse Studies 1 (2): 159-174. 
Jessop, Bob. 2010. "Cultural political economy and critical policy studies." Critical Policy Studies 3 (3-4): 336-356.

Lužar Šajt, Dušanka, Sonja Gavez, Vanja Hazl, Julija Marošek, Stojan Zagorc, Simona Zagorc, Maja Gorjanc, Zdenka Kovač and Davide Branco. 2005. Študija obstoječega stanja na področju socialne ekonomije v Sloveniji: s priporočili za pripravo modela uvajanja socialnega podjetništva. 2005. Ljubljana, JAPTI, Javna agencija RS za podjetništvo in tuje investicije.

Macura, Rajko and Iva Konda. 2016. "Social Entrepreneurship: an Instrument of Social and Development Policy." Journal of Economic and Business Sciences 3 (2): $20-35$.

Mair, J. and Martí Lanuza, I. 2006. Social entrepreneurship research: A source of explanation, prediction, and delight. Journal of World Business 41 (1): 3644.

Makarovič, Matej, Janez Šušteršič and Borut Rončević. 2014. "Is Europe 2020 se to fail? The Cultural Political Economy of the EU Grand Strategies." European Planning Studies 22 (3): 610-626.

Makingrilas, Jureeporn, Vichai Lamsutthi, Rattasart Phongphaew, Thuchapon Yodthong. 2016. "The model of social entrepreneurs influencing economic and social security." International Journal on Advanced Research 4 (5): 447454.

Ministry of Economic Development and Technology. N.d. Social Enterpreneurship.

http://www.mgrt.gov.si/si/delovna_podrocja/socialno_podjetnistvo/. Accessed. May 2, 2019.

National guidelines to improve built environment, information and communications accessibility for people with disabilities. Official Gazette of RS, No. 113/05.

OECD/European Commission. 2013. Policy Brief on Social Entrepreneurship. Entrepreneurial Activities in Europe. Luxembourg: Publications Office of the European Union. 
Phan, Phillip H. 2014. "Introduction." Theory and Empirical Research in Social Entrepreneurship, edited by Phillip H. Phan, Sophie Bacq and Mattias Nordqvist. Cheltenham, UK / Northampton, MA, USA: Edward Elgar.

Podmenik, Dane, Frane Adam, Goran Milosevic, 2017. The Challenges of Social Entrepreneurship in Slovenia. 6th EMES International Research Conference on Social Enterprise, 2017.

http://programme.exordo.com/6emesconf/delegates/presentation/328/. Accessed July 3, 2018.

Programme of Measures 2014-2015 for conducting the Strategy for Social Entrepreneurship. Republic of Slovenia.

http://www.mgrt.gov.si/fileadmin/mgrt.gov.si/pageuploads/mddsz.gov.si/ pageuploads/dokumenti_pdf/zaposlovanje/Program_ukrepov_20142015_za_izvajanje_strategije_razvoja_socialnega_podjetnistva.pdf . Accessed July 3, 2018.

Regulation on Determination of Activities of Social Entrepreneurship. 2012. Official Gazette of RS, No. 54/12, amend. 45/14.

Resolution on the Master Plan for Adult Education in the Republic of Slovenia for 2013-2020. 2013. Official Gazette of RS, No. 90/13.

Rončević, Borut. 2008. Strateško usmerjanje v sodobni družbi. (Strategic Steering in Contemporary Society). Nova Gorica: Fakulteta za uporabne družbene študije.

Rončević, Borut, Matej Makarovič. 2011. "Societal Steering in Theoretical Perspective: Social Becoming as an Analyical Solution." Polish Sociological Review 176 (4), 461-472.

Rončević, Borut, Matej Makarovič. 2010. "Towards the Strategies of Modern Societies: Systems and Social Processes." Innovation - The European Journal of Social Science Research 23 (3): 223-239.

Rončević, Borut, Janez Šušteršič, Peter Wostner, Tamara Besednjak Valič. 2010. "Quo vadis Slovenia? Between framework conditions and internal capabilities." Managing Global Transitions: International Research Journal, 8 (4): 353-380. 
Rules on Monitoring Operations of Social Enterprises. 2013. Official Gazette of RS, No. 35/13.

Slovenian Accounting standards. 2016. Official Gazette of RS, No. 95/15, amend. 74/16, 23/17.

Social Entrepreneurship Act. 2011. Official Gazette of RS, No. 20/2011, amend. 90/14.

Social Entrepreneurship Act. 2018. Official Gazette of RS, No. 20/2011, amend. 90/14 and 13/18.

Spear, Roger, Giulia Galera, Antonella Noya, Emma Clarence. 2010. "Improving Social Inclusion at the Local Level Through the Social Economy: Report for Slovenia", OECD Local Economic and Employment Development (LEED) Working Papers, 2010/16, OECD Publishing, Paris. http://dx.doi.org/10.1787/5kg0nvfx2g26-en.

Strategy for Social Entrepreneurship for the period 2013-2016. 2013. Republic of Slovenia.

http://www.mgrt.gov.si/si/delovna_podrocja/socialno_podjetnistvo/. Accessed February 2, 2019.

Šent. 2013. Rezultati raziskave o podpornem okolju za razvoj socialnega podjetništva $v$ Sloveniji.

http://www.sentprima.com/wp-content/uploads/2015/10/rezultatiraziskave-o-podpornem-okolju.pdf

Šent. 2014. Razvoj modela učnih delavnic v socialnih podjetjih tipa b izvajalec: šent - slovensko združenje za duševno zdravje. Ministry of Labour, Family, Social Affairs and Equal Opportunities of the Republic Slovenia.

http://www.mgrt.gov.si/fileadmin/mgrt.gov.si/pageuploads/mddsz.gov.si/ pageuploads/dokumenti_pdf/zaposlovanje/Studija.pdf. Accessed July 3, 2018.

Tomaževič, Nina and Aleksander Aristovnik. 2018. Social Entrepreneurship: Case of Slovenia. Case Study. Ljubljana: Zavod 14.

Tomaževič, Nina and Cantele, Silvia. 2019. "Handbook of Research on Value Creation for Small and Micro Social Enterprises." Social Entrepreneurship and 
Social Enterprises in Slovenia: Strengths and Weaknesses From an Analysis of the Institutional Framework. IGI Global.

Torres Coronas, Teresa and María Arántzazu Vidal Blasco. 2013. Social EEnterprise: Value Creation through ICT: Value Creation through ICT. Hershey/PA: GI Global.

Trampuš, Marina, Franc Cankar and Stanka Setnikar Cankar. 2013. "From project to social enterprise." Učenje za poduzetništvo 3 (2): 162-169.

Vocational Rehabilitation and Employment of Disabled Persons Act. 2004. Official Gazette of RS, No. 16/07, amend. 87/11, 96/12, 98/14. 